\title{
Hydrological changes in the Ligurian Sea (NW Mediterranean, DYFAMED site) during 1995-2007 and biogeochemical consequences
}

\author{
J. C. Marty ${ }^{1,2}$ and J. Chiavérini ${ }^{3,4}$ \\ ${ }^{1}$ CNRS, UMR 7093, LOV, Observatoire océanographique, 06234, Villefranche/mer, France \\ ${ }^{2}$ UPMC Univ Paris 06, UMR 7093, LOV, Observatoire océanographique, 06234, Villefranche/mer, France \\ ${ }^{3}$ CNRS, UMS 829, Observatoire océanographique, 06234, Villefranche/mer, France \\ ${ }^{4}$ UPMC Univ Paris 06, UMS 829, Observatoire océanographique, 06234, Villefranche/mer, France
}

Received: 9 February 2010 - Published in Biogeosciences Discuss.: 22 February 2010

Revised: 1 July 2010 - Accepted: 1 July 2010 - Published: 7 July 2010

\begin{abstract}
Data obtained during the monthly cruises of the DYFAMED time-series study (northwestern Mediterranean Sea) in the period 1995-2007 were compiled to examine the hydrological changes and the linked variation of some biogeochemical characteristics (nutrients and pigments). A regular increase of temperature and salinity $\left(0.005^{\circ} \mathrm{Cy}^{-1}\right.$, $0.0022 \mathrm{psu}^{-1}$ ) was recorded in deep waters of the NW Mediterranean Sea (2000 $\mathrm{m}$ depth) during 1995-2005. In February 2006 an abrupt increase in $T\left(+0.1^{\circ} \mathrm{C}\right)$ and $S$ $(+0.03 \mathrm{psu})$ was measured at $2000 \mathrm{~m}$ depth as the result of successive intense winter mixing events during the 3 previous years. The February 2006 event led to the mixing of the whole water column (0 to $>2000 \mathrm{~m})$ and increased salt and heat content of the Western Mediterranean Deep Water by mixing with saltier and warmer Levantine Intermediate Water. The deficit in fresh water inputs to the western Mediterranean basin in three successive years (2003-2005) was suspected to be the major cause of this event since an increase of salinity in surface waters was monitored during these years. The measured phytoplankton biomass was specifically high after the periods of intense mixing. Chlorophyll $a$ integrated biomass reached $230 \mathrm{mg} \mathrm{m}^{-2}$ in $1999,175 \mathrm{mg} \mathrm{m}^{-2}$ in 2003 , and $206 \mathrm{mg} \mathrm{m}^{-2}$ in 2006. The high levels of biomass were related to the particularly high increases in nutrients content in surface layers following the intense water column mixing and the subsequent development of a diatom bloom (as seen by fucoxanthin content). The occurrence of extreme events
\end{abstract}

Correspondence to: J. C. Marty (marty@obs-vlfr.fr) (high mixing, high nutrients, and high biomass) increased in recent drought years (2003 to 2006). Our results indicated that the NW Mediterranean Sea productivity is increasing.

\section{Introduction}

A progressive increase in temperature and salinity of the Western Mediterranean Deep Water (WMDW) has been reported since the 1960's (Bethoux et al., 1990; Rohling and Bryden, 1992; Krahmann and Schott, 1998; Bethoux and Gentilli, 1999; Astraldi et al., 2002). The rate of this increase (ca. $0.0035^{\circ} \mathrm{C} \mathrm{y}^{-1}$ for temperature, $0.001 \mathrm{psu} \mathrm{y}^{-1}$ for salinity during the 1959-1997 period, Bethoux et al., 1998) appears to have accelerated in the recent years (Rixen et al., 2005). The processes responsible of these increases in temperature and salinity are still matter of debate. These deep water trends have been attributed to long term changes in freshwater and heat fluxes of the Mediterranean Sea in relation to climatic/anthropogenic changes. Explanations have implicated the higher salinity of Intermediate Water (LIW) linked to reductions in freshwater budget in the eastern basin (via river damming and decrease of precipitations) and consecutive changes in the LIW salinity during formation in the eastern basin (Bethoux and Gentili, 1999; Skliris and Lascaratos, 2004; Rohling and Bryden, 1992; Schroeder et al., 2006). Local increase in surface salinities in the western Mediterranean may also be the cause of deep waters trends (Krahmann and Schott, 1998). Bethoux et al. (1990) proposed that the deep-water temperature trend may be the result of greenhouse-gas-induced local warming. Recent works

Published by Copernicus Publications on behalf of the European Geosciences Union. 
indicate that the deep trends are probably the result of a combination of both salinity increase in LIW and increasing surface salinity in the WMDW formation sites (Skliris et al., 2007) propagated by winter surface waters cooling, or changes in the characteristics of the inflowing Atlantic water (Millot et al., 2006).

Following the work of the MEDOC group (1970), the process of winter deep convection has been extensively described (Leaman and Schott, 1991; Bethoux et al., 1990; Testor and Gascard, 2006; Smith et al., 2008). During the winter months, deep convection principally in localised regions of the Gulf of Lions forms the WMDW by mixing of surface waters and subjacent LIW. Additionally, cooling and mixing of Gulf of Lions coastal and off-shelf waters during winter provokes cascading of dense waters along submarine canyons (Canals et al., 2006). In the western Mediterranean Sea the principal important area of deep water formation is the Gulf of Lions (MEDOC area) (Lopez-Jurado et al., 2005) even if less intense events of dense water formation have been reported in the Balearic Sea (Salat and Font, 1987) and in the Ligurian Sea (Sparnocchia et al., 1995). The events of dense water formation are more or less intense owing to the annual winter decrease of temperature and increase of wind activity which increases evaporation. The key role of salinity in the increase of surface densities has been underlined (Bethoux and Gentili, 1999; Skliris et al., 2007).

Hydrologic observations in the western Mediterranean Sea have indicated important changes in temperature and salinity of WMDW in recent years.

Abrupt disruption of the long-term warming trend was observed in the Balearic Sea in summer 2005 (Lopez-Jurado et al., 2005; Font et al., 2007). In the Ligurian Sea in 2006, Smith et al. (2008) have recorded the more saline, warmer and denser deep water ever recorded in the western Mediterranean deep water.

The winter deep convection events allow the replenishment in nutrients of the surface layers and in this sense they are the support of phytoplankton new production. Recent observations and models indicate a tendency for oceans towards a decrease of phytoplankton productivity (e.g. Sarmiento et al., 2004; Behrenfeld et al., 2006; Doney, 2006). This decrease of productivity would be linked to enhanced upper stratification and slowed deep water formation as a response to warming climate (Boyd and Doney, 2002; Polovina et al., 2008). But a slight increase of phytoplankton biomass from 1991-1999 has been observed in the NW Mediterranean (Marty et al., 2002).

In this paper the 12-year hydrological data collected monthly in the Ligurian Sea at DYFAMED (DYnamique des Flux Atmosphériques en MEDiterranée) time series station during 1995-2007 were analyzed. Long term trends are derived for temperature and salinity in the various water masses. The winter 2006 intense convection event is highlighted. The connection between intensity of the winter convection events and new availability of nutrient in the surface layer is examined in relation to the phytoplankton biomass. The connection between hydrologic changes observed and variations in different groups of phytoplankton biomass is examined.

\section{Materials and methods}

Data were obtained during the monthly cruises of the DYFAMED time-series study initiated in the course of the JGOFS (Joint Global Ocean Flux Studies) France Program (Marty et al., 2002). The DYFAMED site is located $50 \mathrm{~km}$ off Cape Ferrat, at $43^{\circ} 25^{\prime} \mathrm{N}, 7^{\circ} 52^{\prime} \mathrm{E}$ in the Ligurian Sea, where the water depth is $2350 \mathrm{~m}$ (Fig. 1). During the near-monthly routine survey, systematic deep casts down to $2000 \mathrm{~m}$ where realized since 1995 using a CTD (SeaBird SBE 911plus) mounted on carousel (SBE 32) equipped with 12 bottles (121 Niskin). In rare occasions, casts were obtained down to $2300 \mathrm{~m}$. The probes (temperature SBE 3-02F, conductivity SBE 4-02/0) were returned to Sea-Bird once a year for routine calibrations.

The samplings for pigment and nutrient analyses were conducted on the CTD casts. For pigments, each profile was constituted of 12 samples in the $0-200 \mathrm{~m}$ layer. Pigment analysis was achieved on 31 samples by HPLC using the method of Vidussi et al. (1996). The total procedure is developed in Marty et al. (2002). Phytoplankton pigments were measured all along the survey. The concentrations of chlorophyll $a$ (in fact the chlorophyll $a$ reported here is the total chlorophyll $a$ : chlorophyll $a+$ divinylchlorophyll $a+$ chlorophyll $a$ allomers and epimers) and other significant pigments were integrated over the 0-200 m layer. Samples for nutrient analysis were obtained from CTD casts (22 samples for the 0-2000 m layer) and were analyzed using standard automated colorimetric procedures using an autoanalyser according to Tréguer and Le Corre (1975).

The results of the first years (1991-1999) of the multidisciplinary time-series were discussed and methods employed were described by Marty et al. (2002).

\section{Results and discussion}

\subsection{Water masses in the central Ligurian Sea}

The hydrological data set which was collected at the DYFAMED site during the monthly survey from 1995 to 2007 revealed the principal characteristics of the water masses present in the Ligurian Sea. The potential temperature vs. salinity $(T S)$ diagram of the whole data set is presented in Fig. 2a. The three major typical water masses of the western Mediterranean Sea were evidenced: the WMDW ( $T \sim 12.8^{\circ} \mathrm{C}$ and $\left.S \sim 38.43-38.46 \mathrm{psu}\right)$, the LIW $(T \sim 13.2$ to $13.5^{\circ} \mathrm{C} ; S \sim 38.5$ to $38.6 \mathrm{psu}$ ) and the surface water MAW (Modified Atlantic Water) with seasonally variable 


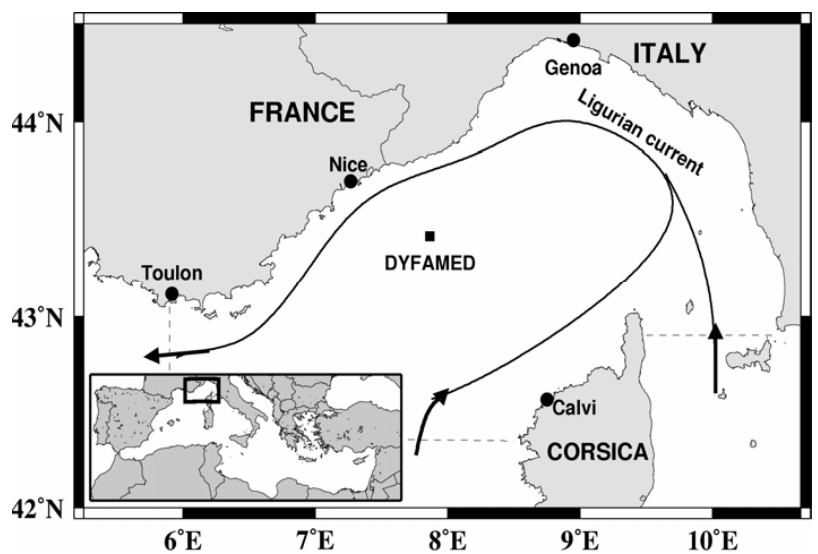

Fig. 1. Location of the DYFAMED time-series station in the Ligurian Sea, North-western Mediterranean.

characteristics. This situation was conforming to what was described earlier (e.g. Bethoux et al., 1998; Millot, 1999).

The surface water (MAW) which extended to a depth of about $200 \mathrm{~m}$ was subject to strong seasonal influence of heat and water exchanges with the atmosphere. The MAW is considered as mostly affected by local climatic conditions (Schroeder et al., 2006). It is constituted by the inflowing of Atlantic waters which are largely modified by local environmental constraints during their transit. Its temperature was highly variable during the year (from 12.8 to $>25^{\circ} \mathrm{C}$ for the first meters in summer). The salinity was also very variable during the time-series in the range 37.7 to 38.5 psu.

The LIW is formed in the eastern basin. Its characteristics have changed during the shift of the deep water formation site from the southern Adriatic to the Aegean Sea, an event called Eastern Mediterranean transient (EMT) (Roether et al., 1996; Klein et al., 1999; Lascaratos et al., 1999). The EMT event affected the eastern Mediterranean Sea in the late 80's (Lascaratos et al., 1999). At the DYFAMED site, the LIW was extending approximately between 200 and $600 \mathrm{~m}$ depth (Fig. 2b). It was characterized by a maximum of salinity and temperature in the range $13.2-13.5^{\circ} \mathrm{C}, 38.5-38.6 \mathrm{psu}$ in agreement with that indicated by Millot (1999). The maximum salinity was located above the maximum temperature.

The WMDW is formed in the Liguro-Provençal basin mainly from MAW-LIW mixture (Millot et al., 2006). The "pure" WMDW is considered to be roughly below $2000 \mathrm{~m}$ (e.g. van Haren and Millot, 2004) whenever the upper part of the WMDW is constituted by mixing of LIW and dense waters from the Tyrrhenian Sea (Millot, 1999; Millot et al., 2006). In our data, the vertical profiles of temperature and salinity (Fig. 2b) indicated that the "pure" WMDW was present below 1600/1800 $\mathrm{m}$ depth. Some profiles discarded from the general tendency (2006 profiles in red); this was particularly visible by the WMDW values of temperature and salinity on Fig. $2 b$.

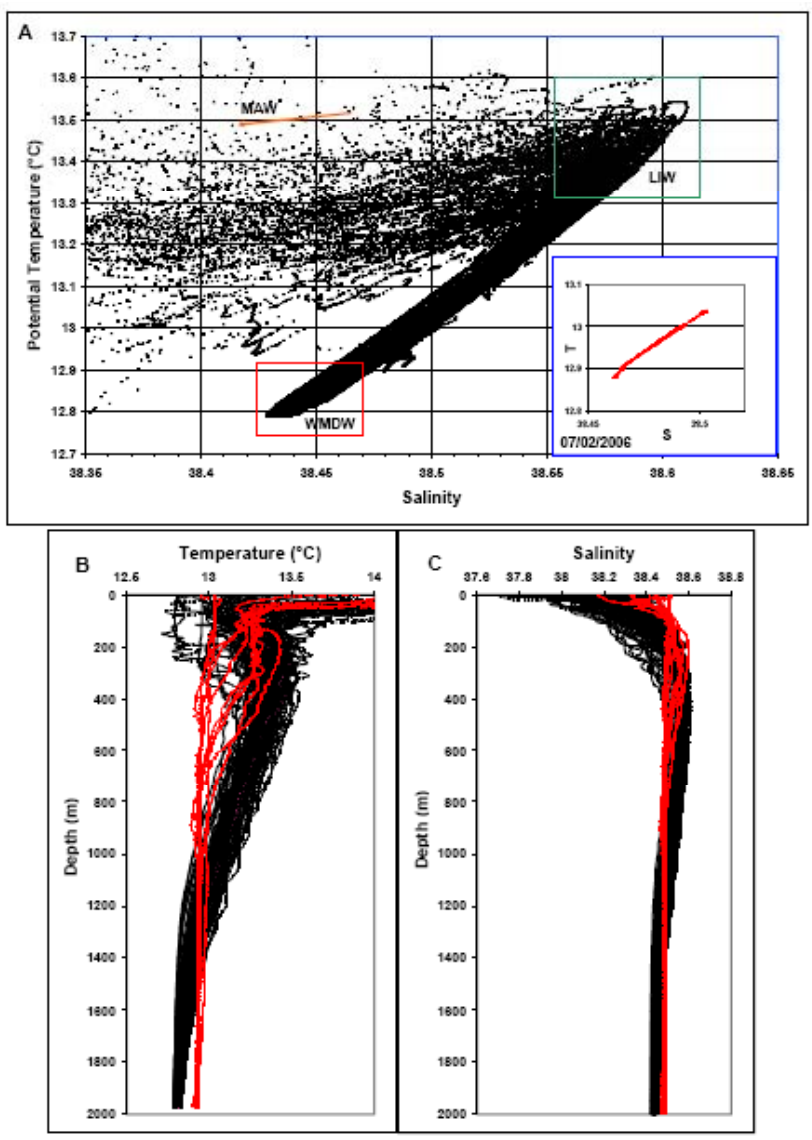

Fig. 2. Hydrological characteristics for the 1995-2007 dataset at DYFAMED. (A) Potential temperature vs. salinity $(T S)$ diagram for the whole dataset (1995-2006, last profiles in January 2007). The $T S$ diagram in the inset (right corner) is for the 7 February 2006 profile. (B) Potential temperature profiles (2006 profiles are in red). (C) Salinity profiles (2006 profiles in red).

Hereafter we will consider $350 \mathrm{~m}$ and $1974 \mathrm{~m}$ (we cannot use $2000 \mathrm{~m}$ since some profiles were stopped just above this depth) for the monitoring of the temporal variations of LIW and WMDW respectively. The contour plot of potential temperature and salinity over the $0-2000 \mathrm{~m}$ layer is presented for the DYFAMED time-series from 1995 to 2007 on Fig. 3. It appears that potential temperature and salinity presented a strong contrast between most of the survey and the last two years. These two periods will be examined successively.

\subsection{Hydrological trends (period 1995-2005)}

Many authors have estimated the increase of temperature and salinity in WMDW (Table 1). Their estimations vary depending on the period, location and depth. We present here for the first time a direct measure of this increase during 12 years at high frequency (monthly) and on the same site. Our data in the WMDW (near $2000 \mathrm{~m}$ depth, $1974 \mathrm{~m}$ for operational reasons) indicated a regular increase of potential temperature 
Table 1. Literature review of the estimates of annual increases and abrupt changes in potential temperature and salinity of the WMDW.

\begin{tabular}{|c|c|c|c|c|c|}
\hline Station/Zone & Depth & Period & $T$ Tendency & $S$ Tendency & References \\
\hline \multicolumn{6}{|l|}{ Progressive increase } \\
\hline Western Med. Sea & $>2000 \mathrm{~m}$ & 1960-1990 & $4 \times 10^{-3}{ }^{\circ} \mathrm{Cy}^{-1}$ & $1.1 \times 10^{-3} \mathrm{psu} \mathrm{y}^{-1}$ & Bethoux et al., 1990. \\
\hline Algero-Provençal basin & WMDW & 1959-1997 & $3.4 \times 10^{-4}{ }^{\circ} \mathrm{Cy}^{-1}$ & $1.05 \times 10^{-3}$ psu y $^{-1}$ & Bethoux et al., 1998. \\
\hline Gulf of Lions & $1850-2050 \mathrm{~m}$ & $\begin{array}{l}1969-1977 \\
1977-1987\end{array}$ & $\begin{array}{l}2.2 \times 10^{-3}{ }^{\circ} \mathrm{Cy}^{-1} \\
2.6 \times 10^{-3}{ }^{\circ} \mathrm{Cy}^{-1}\end{array}$ & $1.9 \times 10^{-3}$ psu y $^{-1}$ & Leaman and Schott, 1991. \\
\hline Gulf of Lions & $>1000 \mathrm{~m}$ & $1960-1995$ & $16 \times 10^{-4}{ }^{\circ} \mathrm{Cy}^{-1}$ & $8 \times 10^{-4} \mathrm{psu} \mathrm{y}^{-1}$ & Krahmann and Schott, 1998. \\
\hline $\begin{array}{l}\text { North Africain coast and } \\
42^{\circ} \mathrm{N}\left(0-10^{\circ} \mathrm{E}\right)\end{array}$ & $2000 \mathrm{~m}$ & 1909-1990 & $8.3 \times 10^{-4}{ }^{\circ} \mathrm{Cy}^{-1}$ & $6.9 \times 10^{-4}$ psu y $^{-1}$ & Rohling and Bryden, 1992. \\
\hline Western Med. Sea & $2000 \mathrm{~m}$ & $\begin{array}{l}<1960 \\
>1960\end{array}$ & $\begin{array}{l}8 \times 10^{-4}{ }^{\circ} \mathrm{Cy}^{-1} \\
2.5 \times 10^{-3}{ }^{\circ} \mathrm{Cy}^{-1}\end{array}$ & $\begin{array}{l}6 \times 10^{-4} \mathrm{psu} \mathrm{y}^{-1} \\
1.1 \times 10^{-3} \mathrm{psu} \mathrm{y}^{-1}\end{array}$ & Tsimplis and Baker, 2000. \\
\hline Western Med. Sea & $>600 \mathrm{~m}$ & $1950-2000$ & $1.8 \times 10^{-3}{ }^{\circ} \mathrm{Cy}^{-1}$ & $7 \times 10^{-4}$ psu y $^{-1}$ & Rixen et al., 2005. \\
\hline DYFAMED & $2000 \mathrm{~m}$ & $1995-2005$ & $5 \times 10^{-3}{ }^{\circ} \mathrm{Cy}^{-1}$ & $2.2 \times 10^{-3} \mathrm{psu} \mathrm{y}^{-1}$ & This Work \\
\hline \multicolumn{6}{|l|}{ Abrupt Changes } \\
\hline Balearic Sea & $>600 \mathrm{~m}$ & 2005 & $0.14^{\circ} \mathrm{C}$ decrease & & Lopez-Jurado et al., 2005. \\
\hline Algero-Provençal Basin & $600-1400 \mathrm{~m}$ & 2004-2005 & $0.12^{\circ} \mathrm{C}$ decrease & $0.015 \mathrm{psu}$ decrease & Lopez-Jurado et al., 2005. \\
\hline Off Catalan coast & $1890 \mathrm{~m}$ & winter 2004-2005 & $\begin{array}{l}0.1^{\circ} \mathrm{C} \text { increase } \\
\& 0.3^{\circ} \mathrm{C} \text { decrease }\end{array}$ & $\begin{array}{l}0.03 \text { psu increase } \\
\& 0.03 \text { psu decrease }\end{array}$ & Font et al., 2007. \\
\hline DYFAMED & $2000 \mathrm{~m}$ & March 2006 & $0.1^{\circ} \mathrm{C}$ increase & 0.03 psu increase & This Work \\
\hline
\end{tabular}
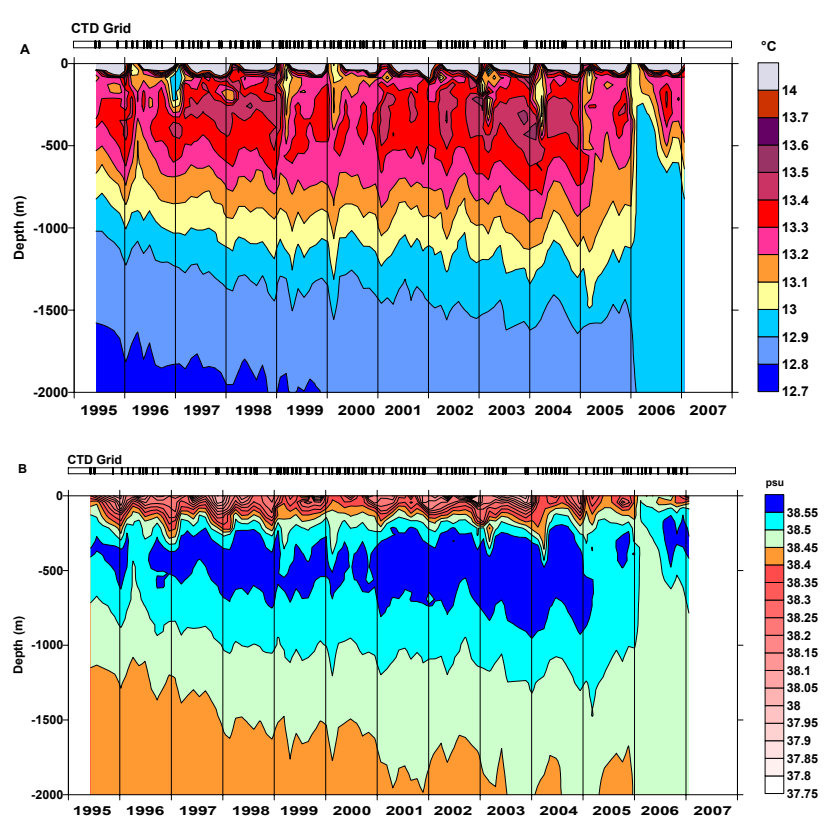

Fig. 3. Contour plots of potential temperature $\left(\mathbf{A},{ }^{\circ} \mathrm{C}\right)$ and salinity $(\mathbf{B}, \mathrm{psu})$ at DYFAMED site, drawn using Surfer program and kriging method. The near-monthly sampling timetable is indicated above the contour plots (CTD Grid).

and salinity from 1995 onwards (Fig. 4b). The density of deep waters during the survey from 1995 to 2007 was slightly increasing ( $\sim 29.10$ to $29.11 \mathrm{Kg} \mathrm{m}^{-3}$, Fig. $\left.4 \mathrm{~b}\right)$. The measured increases of temperature and salinity from 1995 to 2005 were $0.005^{\circ} \mathrm{Cy}^{-1}$ and $0.0022 \mathrm{psu}^{-1}$. They were over the temperature and salinity increase first estimates for the 1960 to
1990 period $\left(0.004^{\circ} \mathrm{Cy}^{-1} ; 0.0011 \mathrm{psu}^{-1}\right)$ (Bethoux et al., 1990) and the other published since this paper (Table 1), and indicated an acceleration of warming and salting in recent years.

Potential temperature and salinity contents of LIW at DYFAMED were relatively stable from 1995 to 2001 and increased from 2002 to 2004 (Fig. 4a), when the density was relatively constant during the survey. Increases in the salinity of LIW in the eastern basin have been reported linked to rivers damming and/or decreasing precipitations (Rohling and Bryden, 1992; Krahman and Schott, 1998; Bethoux and Gentili, 1999). The increase of salinity and temperature observed in the western basin in LIW in 2002-2004 has been attributed to a signal of propagation of EMT in the Western Mediterranean Sea (Lopez-Jurado et al., 2005; Schröder et al., 2006; Font et al., 2007).

During the first months of 1999, 2000, 2003 and 2004, intense but limited in time aberrations (decreases in temperature and salinity of more than $0.2^{\circ} \mathrm{C}$ and 0.05 psu respectively) were noticed. These events were the result of winter mixing with formation of dense water. But only during the winter 2005/2006 the winter convection reached the deep Mediterranean water at $2000 \mathrm{~m}$.

\subsection{Abrupt modifications (2005-2006)}

The major point was the abrupt increase of temperature and salinity in WMDW in 2006. The measured increase in temperature $\left(+0.1{ }^{\circ} \mathrm{C}\right)$ and salinity $(+0.03 \mathrm{psu})$ was about 15 times more than the mean annual increase measured during the 1995-2005 period. This drastic and abrupt increase resulted from intense mixing which was directly recorded 
A
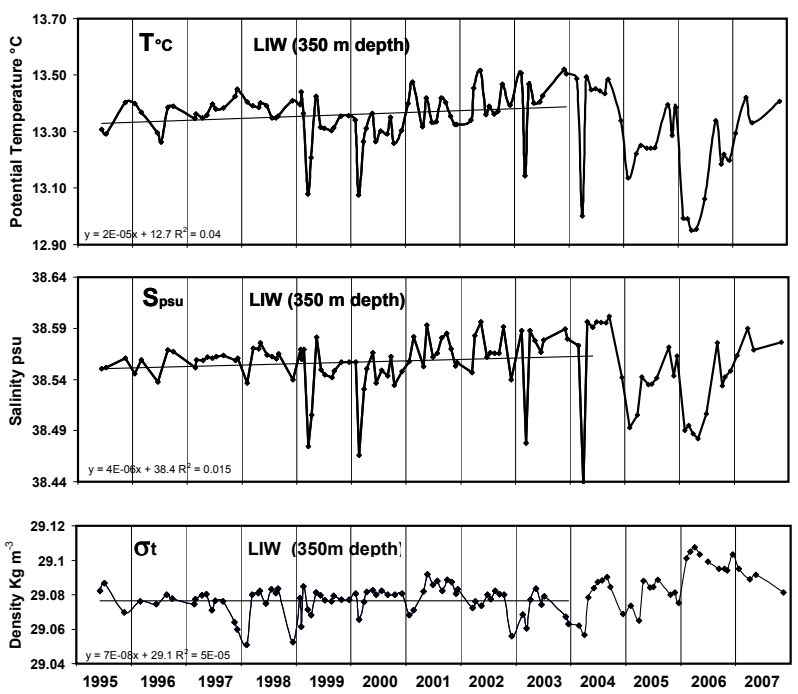

B
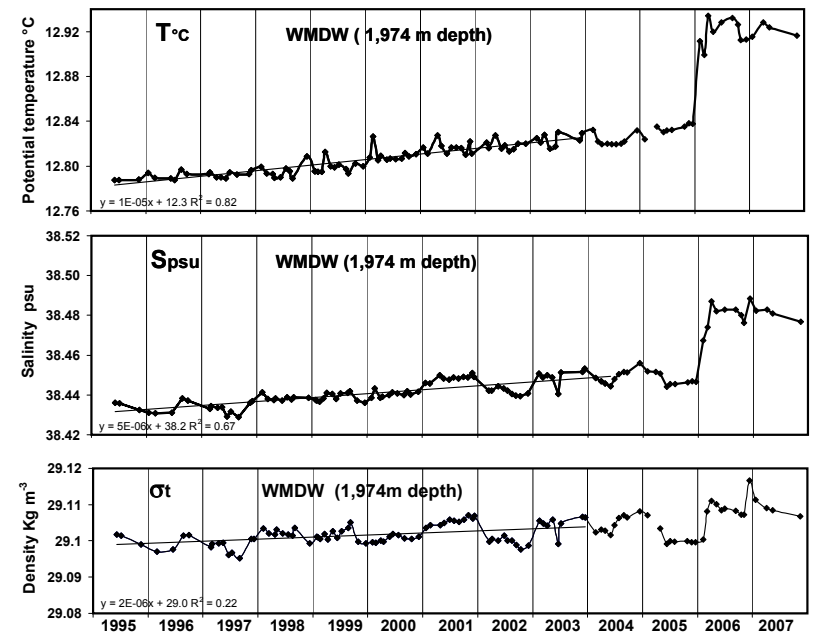

Fig. 4. (A) Potential temperature, salinity and density for LIW (350 m depth) from 1995 to 2007. (A) Potential temperature, salinity and density for WMDW (1974 m depth) for the same period. Regression lines have been drawn for 1995-2003 period.

during the February 2006 cruise. Two deep CTD casts $(>2000 \mathrm{~m}$ ) were performed with a 6 hour delay, each of them giving rise to the same unusual $\theta-S$ diagram (inset in Fig. 2a). The $0-2000 \mathrm{~m}$ water column was entirely described by the small segment $\left(12.85-13.05^{\circ} \mathrm{C} ; 38.46-38.50 \mathrm{psu}\right)$ that indicated an almost complete homogenization of the entire water column.

Strong changes during winter 2004/2005 have been evidenced elsewhere in the western Mediterranean $\left(0.2^{\circ} \mathrm{C}\right.$ and 0.04 psu decreases of temperature and salinity in water down to $1500 \mathrm{~m}$, complex thermohaline structure in deeper levels)
(Lopez-Jurado et al., 2005; Schröder et al., 2006; Smith et al., 2008). Schröder et al. (2006) suggested that the LIW involved in the deep water formation in winter 2004/2005 came mainly from the Ligurian Sea. But in the Ligurian Sea at our observation site during the 2005 event the convection did not reach the deeper water and was limited to a depth of 600 . The processes of deep water convection in the winter 20042005 in Catalan subbasin and in winter 2005-2006 in the Ligurian subbasin have been detailed using Argo floats and some DYFAMED data by Smith et al. (2008). They highlighted the differences in the preconditioning phase in Catalan subbasin and in Ligurian subbasin during the two successive winters. In the Ligurian basin, the convection of winter 2004/2005 down to $600 \mathrm{~m}$ depth decreased T and $S$ in the intermediate waters and resulted in a decrease of density gradient between surface and intermediate waters preconditioning the 2006 event. The illustration is furnished by Fig. 5b: the winter/spring maximum of density of the surface waters $(0-200 \mathrm{~m})$ is regularly increasing from 2002 to 2006 (2002: 28.92; 2003: 28.95; 2004: 29.02; 2005: 29.07; 2006: 29.10) whereas the density of intermediate water $(200-600 \mathrm{~m})$ is almost stable (20.07-29.10).

\subsection{Role of salinity in the $2005 / 2006$ winter mixing event}

The meteorological conditions prevailing during the study are illustrated in Fig. 6. The air temperature and wind speed recorded at "Côte d'Azur" meteorological buoy located at the DYFAMED site since 1999 and the monthly cumulative precipitations recorded at Nice airport are reported (Cote d'Azur Buoy and Nice airport station are operated by Meteo France). Winter 2005-2006 was characterized by a low air temperature (slightly $>10^{\circ} \mathrm{C}$ ) and high wind speed (mean $27 \mathrm{Knts}$ ) during 2 months. Lower winter temperatures were recorded in winter 2004-2005 but during a short time and accompanied with less intense winds. NCEP/NCAR daily reanalysis in the Ligurian Sea during the same periods (Smith et al., 2008) indicated that a significantly lower loss of heat from the sea to the atmosphere was recorded in winter 2005-2006 than in winter 2004/2005.

The evolution of $T$ and $S$ of water masses in years preceding the 2006 event in the Ligurian Sea is illustrated in Fig. 5. The mean temperature and salt contents of the successive layers $(0-200,200-600,600-1600,1600-1974 \mathrm{~m})$ have been reported on Fig. 5a for the whole period and in Fig. 5b for the last four years.

The deeper water masses presented only minor changes during the study with the exception of the 2006 event. The WMDW (1600-1974 m) temperature and salinity evolutions were characterized by a slight and regular increase as highlighted before. The temperature and salinity of the layer 600-1600 m (upper WMDW) was also slightly increasing. The difference between the two layers occurred principally during year 2006 with the strong increase of $T$ and $S$ in the 


\section{A}
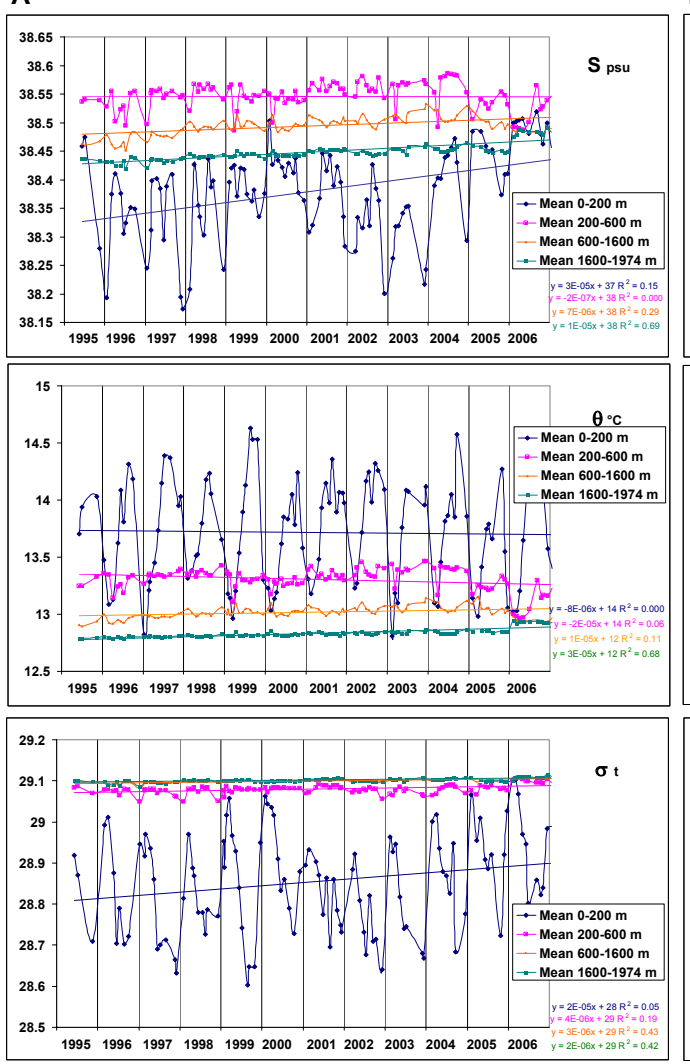

B
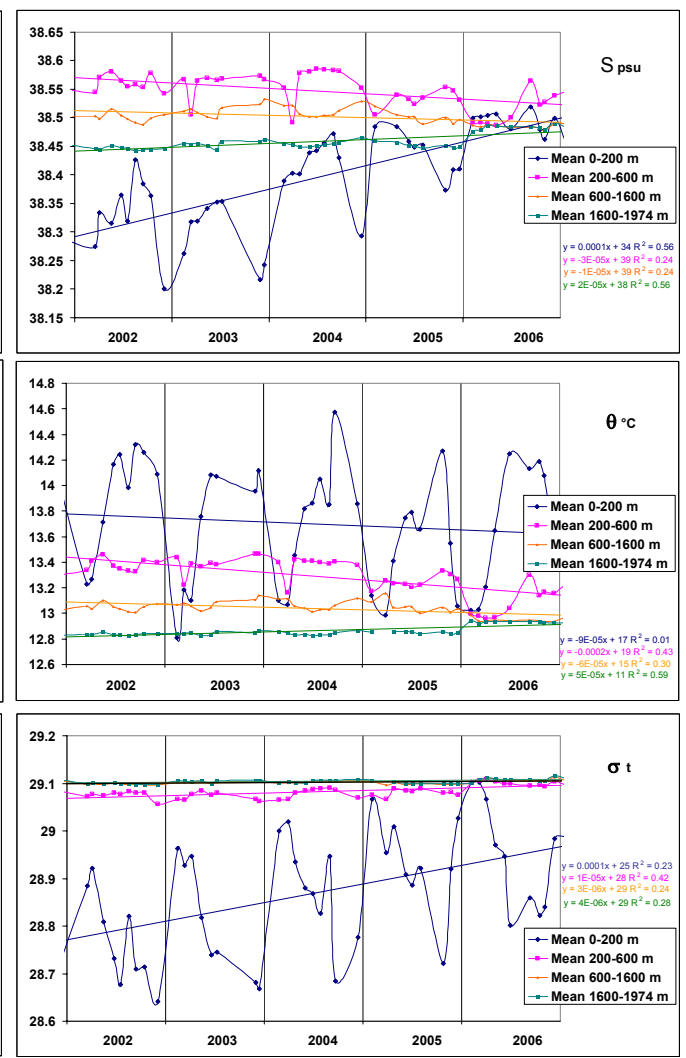

Fig. 5. (A) 1995-2006 time-series of mean salinity, mean temperature, mean density in various layers: 0-200 m; 200-600 m; 600-1600 m, 1600-1974 m. (B) Detail for 2002-2006 period. Regression lines for the 2002-2006 period.

WMDW whenever the intermediate deep layer temperature and salinity decreased in 2006.

Along the 12 years, the mean salt content and temperature of LIW (200-600 m) followed approximately the same variation: they were relatively constant or slightly increasing from 1995 to 2004, and decreased markedly during years 2005 and 2006. The MAW $(0-200 \mathrm{~m})$ mean temperature and salinity were seasonally variable. During the record period, the mean salinity of the surface layer $(0-200 \mathrm{~m})$ was fluctuating with a maximum in year 2000. But in the last three years from 2003 to 2006 the trend was particularly noticeable with an increase of salinity from 38.30 to 38.45 psu from year 2002 to year 2006 (Fig. 5b). On the reverse, the mean temperature of the surface layer presented no clear tendency throughout the observation period. In response to salinity and temperature modifications, the density of the surface layer was increasing in the last years (from 2002 to 2006). Year 2006 was the only one where salinity of intermediate waters and surface waters were of the same order revealing again the particular situation in 2006 for the Ligurian Sea. Consequently, the 2006 winter convection in the Ligurian Sea appeared to be linked to a markedly high salinity in the surface layer and a lower salinity than usual in LIW formed during winter 2005 by the convection event down to $600 \mathrm{~m}$.
The salinity appeared as a key parameter in winter convections. The particular importance of intensity of freshwater inputs in the dense water formation process in the North Occidental Mediterranean area had already been highlighted (Bethoux and Gentilli, 1999; Skliris et al., 2007) along with the importance of salinity as tracer of climatic change effects in this area (Somot et al., 2006). We suggest that the salinity increase in superficial waters could be due to a particularly high cumulated deficit in freshwater budget in the north western Mediterranean basin during the years 2003, 2004 and 2005 , and played probably a key role in the observed winter 2006 process leading to increase of $T$ and $S$ in deep waters of the Ligurian Sea. On Fig. 6c the cumulative monthly precipitations from meteorological stations operated by Meteo France bordering the Ligurian Sea (Nice airport), evidenced the low input of rains during these 3 years in winter as well as annually (between 400 and $600 \mathrm{~mm} \mathrm{y}^{-1}$ ). A decrease in precipitations in the Mediterranean basin has been already described and attributed to climate change effects (Hurrell, 1995). The precipitation heights recorded at Nice airport station, which were approximately twice the heights of the adjacent open sea (Bethoux, 1979), can give a relative indication of the global input of freshwater (rivers and rains) to the Mediterranean Sea (Bethoux and Gentilli, 1999). The 

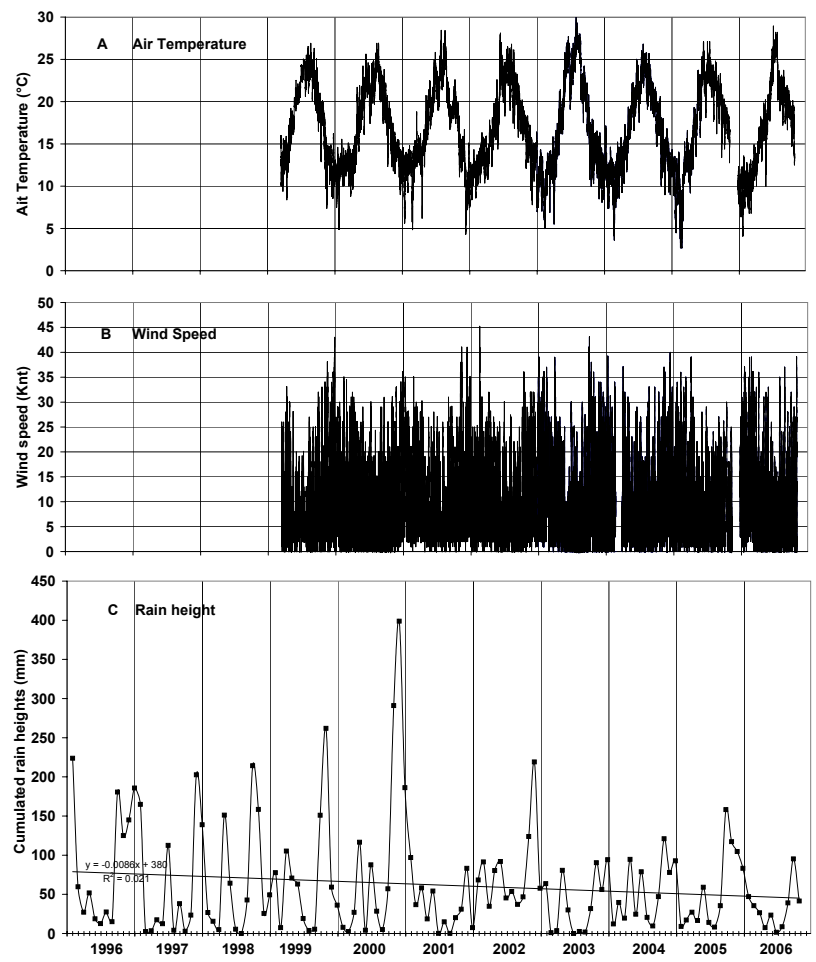

Fig. 6. (A) Air temperature $\left({ }^{\circ} \mathrm{C}\right)$; data from the meteorological "Côte d'Azur" buoy. (B) Wind speed (Knt); data from the meteorological "Côte d'Azur" buoy. (C) Monthly cumulated precipitation heights (mm) during the 1996-2006 period; data from a meteorological station boarding the Ligurian Sea (Nice airport).

year 2003 was the hottest year in Europe (Stott et al., 2004) and 2003, 2004 and 2005 were among the driest (important deficit of rain with respect to the mean for Mediterranean Basin) recorded in the Mediterranean basin. The combination between winter conditions (low temperature and high wind stresses) and high freshwater input deficits for these 3 successive years appeared to be fuelling this drastic convection.

\subsection{Intensity and frequency of winter convections in the Ligurian Sea}

Intense winter convection events have been reported in the literature for the western Mediterranean Sea, principally in the Gulf of Lions (MEDOC group, 1970) and less intense events in the Balearic Sea (Salat and Font, 1987) and in the Ligurian Sea (Sparnocchia et al., 1995). As discussed by Smith et al. (2008), the Catalan subbasin and the Ligurian Sea are unusual locations of deep convections.

The mixed layer depth (MLD calculated as the depth with an increase of 0.04 in density below $10 \mathrm{~m}$ depth) has been reported on Fig. 7 for the survey and showed the depths of annual winter mixings. During our time-series, the MLD was $>2000 \mathrm{~m}$ in 2006. This is to our knowledge the first time that

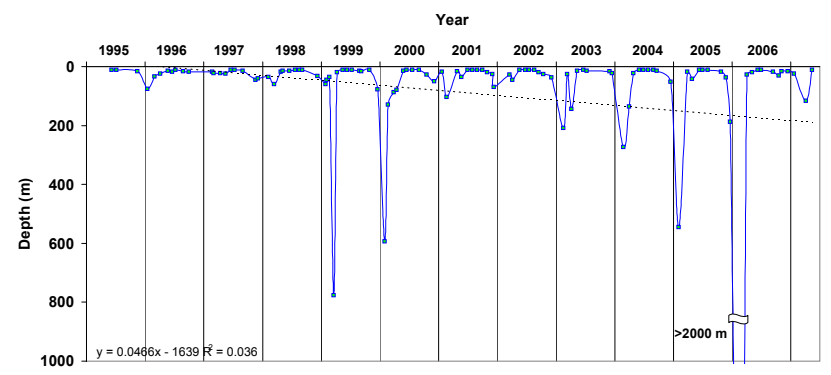

Fig. 7. Mixed layer depth variation and regression line during 19952007 survey at the DYFAMED site, North Western Mediterranean Sea.

a so intense event was directly observed in the Ligurian Sea (inset in Fig. 2a). The one-month frequency of our observations allowed us to detect the frequency and importance of winter convection events during the observation time. During the 1995-2006 period the MLD was >200 $\mathrm{m}$ in 1999 and 2000 and successively in all years from 2003 to 2006. Years 1999 has been already reported as a dense cascading event by Bethoux et al. (2002) who suggested that 1999 was also probably a year of strong convection in the MEDOC area (Gulf of Lions).

Historical data and modelling work indicated that many strong convection events occurred (or should have occurred) in the MEDOC area from 1969 to 1994 (Mertens and Schott, 1998). But since 1994 the principal event recorded in the MEDOC area was the 2005 event (Lopez-Jurado et al., 2005; Schröder et al., 2006; Smith et al., 2008). In the Ligurian Sea no significant event was recorded from 1995 until 1999, but there was a recurrence of events each year from 2003 to 2006. Based on these observations the frequency and intensity of winter convections appeared to be increasing in last years in the Ligurian Sea. Such a trend was predicted by Skliris et al. (2007) as a result of increasing salinities of LIW and increasing surface salinity in the WMDW formation site by a decreasing precipitation trend. The coincidence between the years with low precipitations (2003-2006) and the high convections observed appear to comfort this trend.

\subsection{Winter convections and availability of nutrients}

One of the effects of winter convergences is the replenishment of surface layers with nutrients. In Fig. 8a are reported the nitrate profiles obtained during end winter/early spring cruises (February or March) in the 1995-2006. The nitrate abundance in the $0-50 \mathrm{~m}$ layer was maximum during most of the years when the higher convection events occurred (more specifically 1999, 2004, 2005, and 2006), relatively high during years 2000 and 2003, and was markedly lower during other years. The same classification could have been obtained with the phosphate and silicate profiles. The abundance of nutrients in the surface layer in spring appeared as 


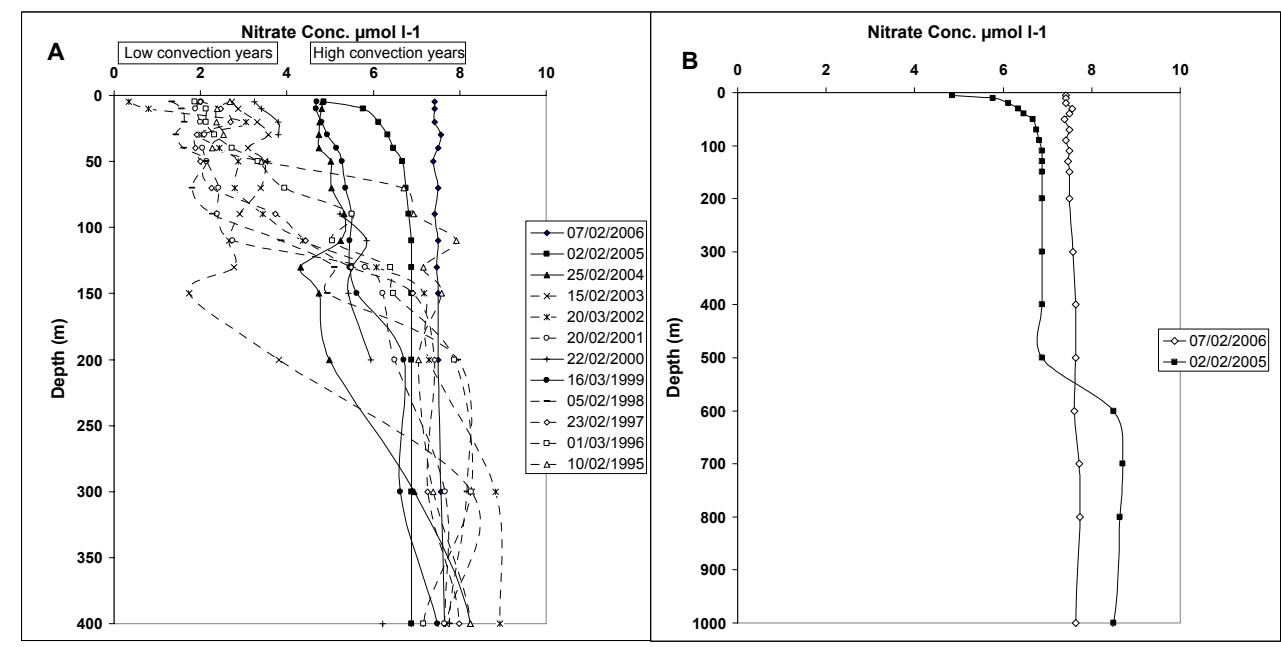

Fig. 8. (A) Nitrate profiles for February/March cruises over the 0-400 m layer during each year (1995-2006, see legend). Concentrations are in $\mu \mathrm{mol} 1^{-1}$. Solid lines for 2006, 2005, 2004, 2000 and 1999 highlight maximum concentrations in the first $50 \mathrm{~m}$ layer. (B) Nitrate profiles for February/March cruises in 2005 and 2006 in the $0-1000$ m layer.
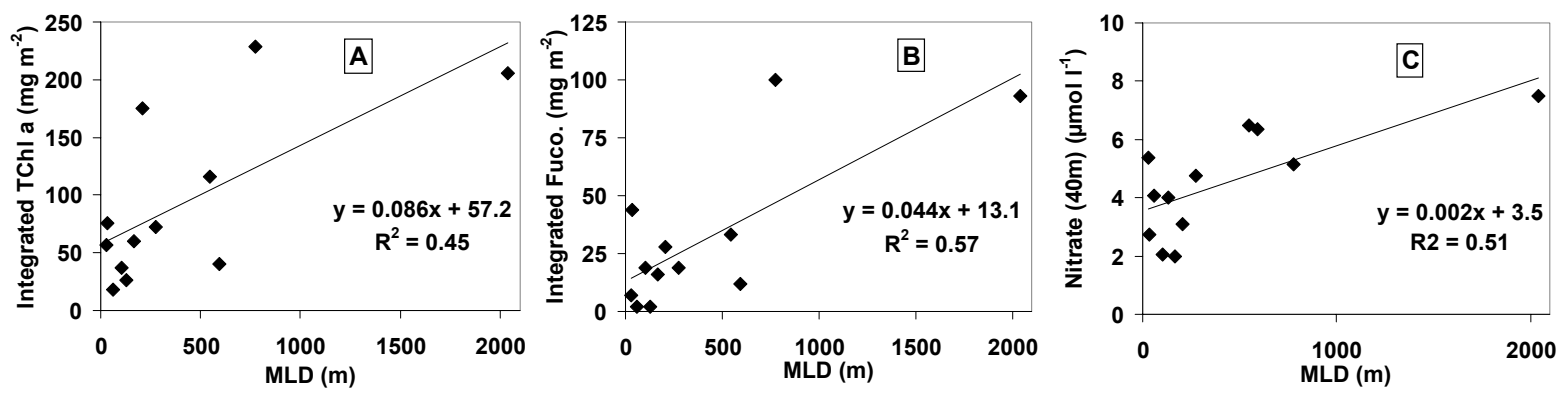

Fig. 9. (A) Correlation between maximum winter MLD and annual integrated chlorophyll $a$; (B) Correlation between maximum winter MLD and annual integrated fucoxanthin. (C) Correlation between maximum winter MLD and maximum nitrate concentration at $40 \mathrm{~m}$ depth in early spring.

directly dependent of the intensity of winter convection (see in Fig. 9 the correlation drawn between the maximum winter MLD and the nitrate concentration at $40 \mathrm{~m}$ depth in early spring).

A focus is given on Fig. $8 \mathrm{~b}$ on the profiles of nutrients for year 2005 and 2006 (where convection events were unusually high and lead to hydrological modifications in the Ligurian Sea). The profile for February 2006 was particularly remarkable since the concentrations of nitrate and phosphate were almost constant (respectively 7.4 and $0.37 \mu \mathrm{mol}^{-1}$ ) all along the water column from the surface to $2000 \mathrm{~m}$. The concentration of silicate in the surface layer was more variable although high (range 6 to $8.5 \mu \mathrm{moll}^{-1}$ ), but differences with nitrate and phosphate profiles could be explained by a different date of sampling for silicate. In February 2005, the nitrate phosphate and silicate profiles were very unusual since they presented very high values in the layer $0-100 \mathrm{~m}$, and a striking difference between the layer 100-500 m (respec- tively $6.8,0.25$ and $4.5 \mu \mathrm{mol}^{-1}$ ) and the layer below $600 \mathrm{~m}$ $\left(8.5,0.35\right.$ and $\left.8 \mu \mathrm{moll}^{-1}\right)$. The MLD in winter 2005 was estimated to $600 \mathrm{~m}$, which appears as the depth where there was a gradient of nutrients between mixed layer and stable underlying deeper waters. Then the nutrient profiles were directly linked to the depth of winter convection.

\subsection{Consequences on phytoplankton biomass}

The integrated chlorophyll $a$ is shown on Fig. 10a for the period 1995 to 2006. The chlorophyll $a$ biomass followed the usual seasonal cycle (Marty et al., 2002). There was a maximum in early spring and lower and relatively constant values were measured during the rest of the year. The concentration range was $20-40 \mathrm{mg} \mathrm{m}^{-2}$ except for bloom periods (usually between end February and April) where higher concentrations $\left(>40 \mathrm{mg} \mathrm{m}^{-2}\right.$ ) were noticed. The yearly maximum occurring in end winter/early spring was, by evidence, linked to 
the new availability of nutrients in the surface layers by the winter mixing. Effectively, high integrated concentrations were recorded during years of high convection; this is particularly clear for 1999 and 2006. The regression of winter maximum MLD versus integrated chlorophyll $a$ is shown in Fig. 9.

The variation of fucoxanthin integrated concentration during the 12-year survey is reported on Fig. 10b. Fucoxanthin is the principal marker of diatoms (Jeffrey, 1980) even if it was also present in primnesyophytes and chrysophytes (Jeffrey and Vesk, 1997). Diatoms are known as opportunistic species (Fogg, 1991) which take advantage of the newly available nutriments after winter mixing. The link between high winter MLD (Fig. 7) and integrated fucoxanthin (Fig. 10b) was even tighter than with chlorophyll $a$. This is illustrated by the correlations between chlorophyll $a$ and fucoxanthin with maximum MLD (Fig. 9). Years 1999, 2000, 2003, 2004, 2005, 2006 where that of maximum of fucoxanthin (over $20 \mathrm{mg} \mathrm{m}^{-2}$ except for 2004, $19 \mathrm{mg} \mathrm{m}^{-2}$ ) and maximum MLD. The only exception was for 1996 where fucoxanthin is high $\left(43 \mathrm{mg} \mathrm{m}^{2}\right)$ and MLD $<100 \mathrm{~m}$. The maximum of phytoplankton biomass in spring was essentially due to a diatom bloom. Diatoms are commonly responsible of spring blooms and likely main contributors to the new production (Goldman, 1993; Claustre, 1994). The occurrence of the diatom bloom in early spring in the Ligurian Sea has been already described at the DYFAMED station (Marty et al., 2002). The year 2006 was particularly remarkable (fucoxanthin maximum was $93 \mathrm{mg} \mathrm{m}^{-2}$ for a chlorophyll $a$ integrated concentration of $206 \mathrm{mg} \mathrm{m}^{-2}$ ). In fact, the chlorophyll $a$ concentration measured at $5 \mathrm{~m}$ depth in April 2006 was the highest recorded during the 12 years of time-series observation $\left(4.3 \mu \mathrm{g} \mathrm{l}^{-1}\right)$. This occurrence of high diatom biomass was related to the abundance of nutrients in surface layers brought by convection events.

The yearly produced phytoplankton biomass would principally be driven by the intensity of spring diatom bloom, since the integrated biomass was much lower and relatively constant for the rest of the year (Marty et al., 2002). In order to evaluate the relative total biomass for each year, an "annual phytoplankton biomass" was calculated as the sum of biomass for each month of the year (When data was missing it was replaced by the mean of the same month for the other years). It must be stressed that this calculation is only indicative since the monthly frequency of our sampling is too low to be certain having captured both the maximum MLD and the maximum phytoplankton biomass. The same calculation was done for chlorophyll $a$ and for the contribution to chlorophyll $a$ of three phytoplankton groups which correspond (with some cautions) to three size classes: microplankton, nanoplankton and picoplankton (Uitz et al., 2006). The results are presented in Fig. 10c.

The increase of chlorophyll $a$ during the period 19952006 was evidenced on Fig. 10a. The measured increase $\left(1.2 \mathrm{mg} / \mathrm{m}^{-2} \mathrm{y}^{-1}\right)$ was slightly lower than the increase ob-
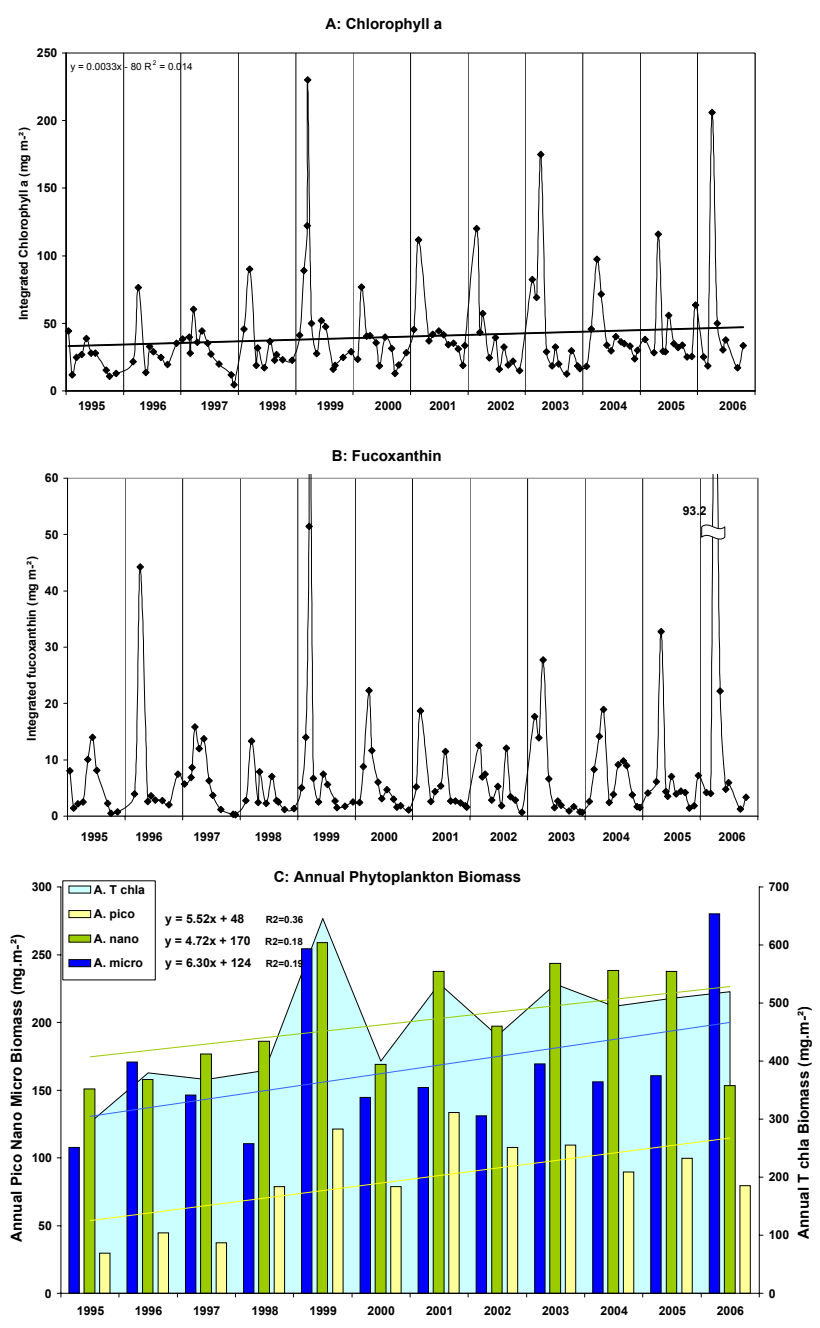

Fig. 10. (A) 1995-2006 time-series of integrated chlorophyll $a$ over the $0-200 \mathrm{~m}$ layer (in $\mathrm{mg} \mathrm{m}^{-2}$ ) and regression line (slope $1.2 \mathrm{mg} \mathrm{m}^{-2} \mathrm{y}^{-1}$ ). (B) 1995-2006 time-series of integrated fucoxanthin. (C) Annual integrated phytoplankton biomass (0-200 m) for total Chlorophyll $a$ and three algal sized classes (pico, nano and micro phytoplankton) and regression lines. A. $T$ chl $a$ : annual chlorophyll $a$; A. pico: annual picophytoplankton; A. nano: annual nanophytoplankton; A. micro: annual microphytoplankton; see text for explanations.

served for the same site during 1991-1999 (range 1.6$3.1 \mathrm{mg} / \mathrm{m}^{-2} \mathrm{y}^{-1}$ ) (Marty et al., 2002). The increase for the whole dataset $(1991-2007)$ is $\left.1.5 \mathrm{mg} / \mathrm{m}^{-2} \mathrm{y}^{-1}\right)$. This increase of phytoplankton biomass for 1995-2007 appeared to be linked both to pico, nano and microphytoplankton as attested by the slope of regression line of the same order for the three classes. Accordingly, the part of chlorophyll $a$ linked for each class is relatively stable during the survey (mean: $37 \%$ micro, $45 \%$ nano, $18 \%$ pico). This was somewhat different of what was observed for 1991-1999 period where the increase of biomass was essentially related to 
small cells (nano and picophytoplankton) as a consequence of the lengthening of the period of stratification linked to climate changes (Marty et al., 2002). In our observations for the period 1995-2006 the chlorophyll $a$ of microphytoplankton also increased. The increase of microphytoplankton (principally diatoms) during the survey was apparently linked to the higher intensity of winter mixing events since 2003.

\section{Conclusions and prospect}

Important changes in hydrology of the western Mediterranean Sea occurred in 2005 and 2006. At the DYFAMED site in the Ligurian Sea, we observed in 2006 an abrupt increase of temperature and salinity of WMDW superimposed over a regular increase since 1995. This abrupt event appeared to be preconditioned by the decrease of freshwater inputs during the 3 preceding years and by a first event in winter 2004-2005. The changes have occurred abruptly following 2004/2005 winter for the west part of Western basin (Lopez-Jurado et al., 2005; Schröder et al., 2006; Font et al., 2007) and in winter 2005/2006 for the Ligurian Sea (this work). These changes could have an impact on the steric level (Tsimplis and Baker, 2000; Tsimplis et al., 2004). It is apparent that deep western Mediterranean Sea presents now a new structure. The increase in deep water temperatures and salinity in the Ligurian Sea was much more important and abrupt than previously measured. We suggest that this exceptional event could be indicative of the high sensibility of the Mediterranean Sea to decrease in freshwater inputs. The extension and intensity of these presumably longlasting changes are beginning to be described (Schroeder et al., 2008). The maintaining and development of time-series stations in the open sea, such as DYFAMED, as well as the use of other tools like the deployment of Argo float (Smith et al., 2008) are essential for the monitoring of long term changes.

An increase of chlorophyll $a$ biomass during the 19952006 period has been evidenced in the Ligurian sea at DYFAMED time-series station. This increase confirms the one observed at the same site during the period 1991-1999 (Marty et al., 2002). But, contrarily to 1991-1999 where nano and pico phytoplankton were the responsible of this increase, microphytoplankton - principally diatoms - appears to play a key role in the increase of the recent years. The greater abundance of this size class was linked to the intensity of phytoplankton blooms in spring, occurring after intense winter convections reaching deep waters. A high phytoplankton biomass production was associated to the intense 2006 convection event as a result of introduction of nutrient in surface waters. Additionally, the intensity of convection events was higher in recent drought years. The high probability of the recurrence of these events through decreasing of freshwater inputs to the north occidental Mediterranean Sea
(Christensen et al., 2007; Giorgi and Lionello, 2008) could confirm the increase of production in the next years.

Acknowledgements. This work has been funded by CNRS/INSU through the DYFAMED Observation Service. We thank MeteoFrance for meteorological data from "Côte d'Azur" buoy and Nice airport station. We thank captain and crew of the RV Tethys II for their cooperative work in the course of the survey. Special thanks are due to A. Stock, A. Dufour, S. Gouy, and F. Girard for the hard work at sea. R. F. C. Mantoura is thanked for useful comments on the early stage of the manuscript.

Edited by: A. V. Borges

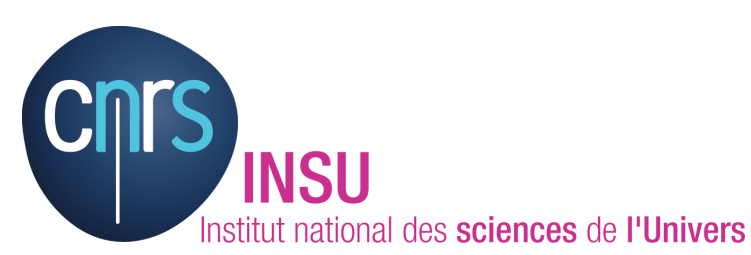

The publication of this article is financed by CNRS-INSU.

\section{References}

Astraldi, M., Gasparini, G. P., Vetrano, A., and Vignudelli, S.: Hydrographic characteristics and internal variability of water masses in the central Mediterranean: a sensitivity test for longterm changes in the Mediterranean Sea, Deep-Sea Res. I, 49, 661-680, 2002.

Bethoux, J. P.: Budgets of the Mediterranean Sea. Their dependence on the local climate and on the characteristics of the Atlantic waters, Oceanol. Acta, 2, 157-163, 1979.

Bethoux, J. P., Durrieu de Madron, X., Nyffeler, F., and Tailliez, D.: Deep water in the western Mediterranean: peculiar 1999 and 2000 characteristics, shelf formation hypothesis, variability since 1970 and geochemical inferences, J. Mar. Sys., 33-34, 117-131, 2002.

Bethoux, J. P., Gentili, B., Raunet, J., and Tailliez, D.: Warming trend in the Western Mediterranean deep water, Nature, 347, 660-662, 1990.

Bethoux, J. P., Gentili, B., and Tailliez, D.: Warming and freshwater budget change in the Mediterranean since the 1940s, their possible relation to the greenhouse effect, Geophys. Res. Let., 25, 1023-1026, 1998.

Bethoux, J. P. and Gentili, B.: Functioning of the Mediterranean Sea: past and present changes related to freshwater input and climate change, J. Mar. Sys., 20, 33-47, 1999.

Behrenfeld, M., O’Malley, R., Siegel, D. A., McLain, C., Sarmiento, J., Feldman, G., Falkowski, P., Boss, E., and Milligan, A.: Climate-driven trends in contemporary ocean productivity, Nature, 444, 752-755, 2006.

Boyd, W. and Doney, S. C.: Modelling regional responses by marine pelagic ecosystems to global climate change, Geophys. Res. Lett., 29(16), 1806, doi:10.1029/2001GL014130, 2002.

Canals M., Puig, P., Durrieu de Madron, X., Heussner, S., Palanques, A., and Fabres, J.: Flushing submarine canyons, Nature, 444, 354-357, 2006. 
Christensen, J. H., Hewitson, B., Busuioc, A., Chen, A., Held, I., Jones, R., Kolli, R. K., Kwon, W.-T., Laprise, R., Magana Rueda, V., Mearns, L., Menendez, G. G., Räisänen, J., Rinke, A., Sarr, A., and Whetton, P.: Regional Climate Projections, in: Climate Change 2007: The Physical Science Basis. Contribution of working group I to the Fourth Assessment Report of the Intergovernmental Panel on Climate Change, edited by: Solomon, S., Qin, D., Manning, M., Chen, Z., Marquis, M.,, Averyt, K. B., Tignor, M., and Miller, H. L., Cambridge University Press, Cambridge, UK and New York, NY, USA, 2007.

Claustre, H.: The trophic status of various oceanic provinces as revealed by phytoplankton pigments signatures, Deep Sea Res. I, 42, 1475-1493, 1994.

Doney, S. C.: Plankton in a warmer world, Nature, 444, 695-696, 2006.

Fogg, G. E.: The phytoplanktonic ways of life, New Phytol., 118, 191-232, 1991.

Font, J., Puig, P., Salat, J., Palanques, A., and Emelianov, M.: Sequence of hydrographic changes in NW Mediterranean deep water due to the exceptional winter of 2005, Scientia Marina, 71, 339-346, 2007.

Giorgi, F. and Lionello, P.: Climate change projections for the Mediterranean region, Global Planet. Change, 63, 90-104, 2008.

Goldman, J. C.: Potential role of large oceanic diatoms in new primary production, Deep Sea Res., 40, 159-168, 1993.

Hurrell, J. W.: Decadal trends in the north Atlantic Oscillation: regional temperature and precipitation, Science, 269, 676-679, 1995.

Jeffrey, S. W.: Algal pigment systems, in: Primary Productivity in the Sea, edited by: Falkowski, P., Plenum Press, New York, 33$58,1980$.

Jeffrey, S. W. and Vesk, M.: Introduction to marine phytoplankton and their pigment signatures, in: Phytoplankton pigments in oceanography, edited by: Jeffrey, S. W., Mantoura, R. F. C., and Wright, S. W., UNESCO, Paris, 37-84, 1997.

Klein, B., Roether, W., Manca, B. B., Bregant, D., Beitzel, V., Kovacevic, V., and Luchetta, A.: The large deep water transient in the Eastern Mediterranean, Deep-Sea Res. I, 46, 371-414, 1999.

Krahmann, G. K. and Schott, F.: Long term increases in Western Mediterranean salinities and temperature: anthropogenic and climatic sources, Geophys. Res. Lett., 25, 4209-4212, 1998.

Lascaratos, A., Roether, W., Nittis, K., and Klein, B.: Recent changes in deep water formation and spreading in the eastern Mediterranean Sea: a review, Prog. Oceanogr., 44, 5-36, 1999.

Leaman, K. D. and Schott, F. A.: Hydrographic structure of the convection regime in the Gulf of Lions: winter 1987, J. Phys. Oceanogr., 21, 575-598, 1991.

Lopez-Jurado, J. L., Gonzalez-Pola, C., and Velez-Belchi, P.: Observation of an abrupt disruption of the log-term warming trend at the Balearic Sea, western Mediterranean Sea, in summer 2005, Geophys. Res. Lett., 32, L24606, doi:10.1029/2005GL024430, 2005.

Malanotte-Rizzoli, P., Manca, B. B., Ribera d'Alcalà, M., Theocharis, A., Brenner, S., Budillon, G., and Ozsoy, E.: The eastern Mediterranean in the 80 s and in the 90s : The big transition in the intermediate and deep circulations, Dyn. Atmos. Oceans, 29, 365-395, 1999.

Marty, J. C.: The DYFAMED time-series program (FrenchJGOFS), Deep-Sea Res. II, 49, 1963-1964, 2002.
Marty, J. C., Chiavérini, J., Pizay, M. D., and Avril, B.: Seasonal and internannual dynamics of nutrients and phytoplankton pigments in the western Mediterranean Sea at the DYFAMED timeseries station (1991-1999), Deep-Sea Res. II, 49, 1965-1986, 2002.

MEDOC Group: Observation of formation of deep water in the Mediterranean Sea, 1969, Nature, 227, 1037-1040, 1970.

Mertens, C. and Schott, F.: Interannual variability of deep-water formation in the northwestern Mediterranean, J. Phys. Oceanogr., 28, 1410-1424, 1998.

Millot, C.: Circulation in the Western Mediterranean sea, J. Mar. Sys., 20, 423-442, 1999.

Millot, C., Candela, J., Fuda, J. L., and Tber, Y.: Large warming and salinification of the Mediterranean outflow due to changes in its composition, Deep Sea Res. I, 53, 656-666, 2006.

Polovina, J. J., Howell, E. A., and Abecassis, M.: The ocean's least productive waters are expanding, Geophys. Res. Lett., 35(3), L03618, doi:10.1029/2007GL031745, 2008.

Rixen, M., Beckers, J. M., Levitus, S., Antonov, J., Boyer, T., Maillard, C., Fichaut, M., Balopoulos, E., Iona, S., Dooley, H., Garcia, M.J., Manca, B., Giorgetti, A., Manzella, G., Mikhailov, N., Pinardi, N., and Zavatarelli, M.: The Western Mediterranean Deep Water : A proxy for climate change, Geophys. Res. Lett., 32, L12608, doi:10.1029/2005GL022702, 2005.

Roether, W., Manca, B., Klein, B., Bregant, D., Georgopoulos, D., Beitzl, V., Kova, V., and Luchetta, A.: Recent changes in Eastern Mediterranean deep waters, Science, 271, 333-335, 1996.

Rohling, E. J. and Bryden, H. L.: Man-induced salinity and temperature increases in the Western Mediterranean deep water, J. Geophys. Res., 97, 11191-11198, 1992.

Salat, J. and Font, J.: Water mass structure near and offshore the Catalan coast during winters of 1982 and 1983, Ann. Geophys., 5B(1), 49-54, 1987.

Sarmiento, J. L., Slater, R., Barber, R., Bopp, L., Doney, S. C., Hirst, A. C., Kleypas, J., Matear, R., Mikolajewicz, U., Monfray, P., Soldatov, V., Spall, S.A., and Stouffer, R.: Response of ocean ecosystems to climate warming, Global Biogeochem. Cy., 18, GB3003, doi:1029/2003GB002134, 2004.

Schröder, K., Gasparini, G. P., Tangherlini, M., and Astraldi, M.: Deep and intermediate water in the western Mediterranean under the influence of the Eastern Mediterranean Transient, Geophys. Res. Lett., 33, L21607, doi:10.1029/2006GL027121, 2006.

Skliris, N. and Lascaratos, A.: Impacts of the Nile River damming on the thermohaline circulation and water mass characteristics of the Mediterranean Sea, J. Mar. Syst., 52, 121-143, 2004.

Skliris, N., Sofianos, S., and Lascaratos, A.: Hydrological changes in the Mediterranean Sea in relation to changes in the freshwater budget: a numerical modelling study, J. Mar. Syst., 65, 400-416, 2007.

Smith, R. O., Bryden, H. L., and Stansfield, K.: Observations of new western Mediterranean deep water formation using Argo floats 2004-2006, Ocean Sci., 4, 133-149, doi:10.5194/os-4133-2008, 2008.

Somot, S., Sevault, F., and Déqué, M.: Transient climate change scenario simulation of the Mediterranean Sea for the twentyfirst century using a high-resolution circulation model, Clim. Dynam., 27, 851-879, 2006.

Sparnocchia, S., Picco, P., Manzella, G. M. R., Ribotti, A., Copello, S., and Brasey, P.: Intermediate water formation in the Ligurian 
Sea, Oceanol. Acta, 18(2), 151-162, 1995.

Stott, P. A., Stone, D. A., and Allen, M. R.: Human contribution to the European heatwawe of 2003, Nature, 432, 610-614, 2004.

Testor, P. and Gascard, J. C.: Post-convection spreading phase in the northwestern Mediterranean Sea, Deep-Sea Res. I, 53, 869-893, 2006.

Treguer, P. and LeCorre, P.: Utilisation de l'autoanalyseur II Technicon. Manuel d'analyses des sels nutritifs dans l'eau de mer, 2nd édition. Laboratoire d'Océanographie chimique, Université de Bretagne Occidentale, France, 110 pp., 1975.

Tsimplis, M. N. and Baker, T. F.: Sea level drop in the Mediterranean Sea : An indicator of deep water salinity and temperature changes?, Geophys. Res. Lett., 27(12), 1731-1734, 2000.
Tsimplis, M. N., Josey, S. A., Rixen, M., and Stanev, E. V.: On the forcing of sea level in the Black Sea, J. Geophys. Res., 109, C09015, doi:10.1029/2003JC002185, 2004.

Uitz, J., Claustre, H., Morel, A., and Hooker, S. B.: Vertical distribution of phytoplankton communities in open ocean: An assessment based on surface chlorophyll, J. Geophys. Res., 111, C08005, doi:10.1029/2005JC003207, 2006.

Van Haren, H. and Millot, C.: Rectilinear and circular inertial motions in the Western Mediterranean Sea, Deep-Sea Res. I, 51(11), 1441-1455, 2004.

Vidussi, F., Claustre, H., Bustillos-Guzman, J., Cailliau, C., and Marty, J. C.: Determination of chlorophylls and carotenoids of marine phytoplankton: separation of chlorophyll $a$ from divinylchlorophyll $a$ and zeaxanthin from lutein, J. Plank. Res., 18, 2377-2382, 1996. 